\title{
Engendering Foreign Direct Investment: Family Structure, Labor Markets and International Capital Mobility
}

\author{
Elissa Braunstein \\ Political Economy Research Institute \\ \& Department of Economics \\ University of Massachusetts, Amherst \\ Amherst, MA 01003 \\ phone: $\quad$ 413-545-6355 (o); 413-369-0277 (h) \\ fax: $\quad 413-545-2921$ \\ email: $\quad$ braunstein@econs.umass.edu
}

\begin{abstract}
In this paper I develop a theoretical foundation for analyzing how gender roles in the household affect foreign direct investment in a developing country context. It is argued that the extent to which women and men share the costs of social reproduction at the household level is a central determinant of women's labor supply and the profitability of investment. I combine a model of family structure with a structuralist macromodel to investigate the effects of various public policies on women's wages and employment. A major goal is to specify the constraints imposed by international capital mobility on the prospects for increased equality and living standards for women.
\end{abstract}

Keywords: structuralist macroeconomics; gender and foreign direct investment; household economics; female labor supply

\section{Acknowledgements}

This paper is the result of significant and essential collaboration with Gerald Epstein at the University of Massachusetts, to whom I am greatly (and gratefully) indebted. I have also benefited from the comments of Nancy Folbre, the Engendering Macroeconomics and International Economics Working Group, and two anonymous referees. 


\section{Engendering Foreign Direct Investment: \\ Family Structure, Labor Markets and International Capital Mobility}

What is the impact of increasing international economic integration on women in developing countries? This question has been a major focus of study for over two decades now. During this time, much has been learned about the gender-specific effects of multinational corporations, export processing zones and structural adjustment (see, for instance, Benería and Feldman 1992; Cagatay, Elson and Grown 1995; Elson 1991; Joekes and Weston 1994; Lim 1990; Standing 1989; UNCTC/ILO 1985; Ward and Pyle 1995). While furthering our understanding a great deal, these studies have also led to some puzzles which relate both to analytical and policy questions. For example, is encouraging foreign direct investment a good vehicle for expanding women's employment? Has the gender wage gap proven resistant to the increased demand for women's labor that often accompanies rising international investment and trade? Why do the economic gains accruing to women from employment in export processing zones sometimes seem frustratingly short-term? Can education and training fortify women's fortunes in the export sector?

Gender-aware analyses of the international economy have been most developed in the area of international trade, partly because of the availability of empirical data and a well defined, but controversial, general equilibrium theory, the Heckscher-Ohlin model. In the area of multinational corporations (MNCs) and foreign direct investment (FDI), the story is different. There is no one widely used theory of multinational corporate investment, and sorting out the components of FDI remains an empirical challenge. Hence, there has been very 
little analysis of the effects of gender relations on FDI and international production, although some have considered the effects of gender asymmetries on export competitiveness (Blecker and Seguino 1998; Seguino 1997).

The other side of these relationships, the effects of MNCs on women and the gendered dimensions of MNC production in developing countries, has gotten more attention. Researchers know something about the nature of wages, employment opportunities, skill requirements and the impact on household relations of women's employment by MNCs, particularly for those operating in export processing zones. Much of the more recent research has focused on the increasing informalization of women's work in international production.

In this article I take up the issue of how gender relations affect multinational operations by developing a macroeconomic model in the structuralist tradition, and considering how women's roles outside the formal market sector impact the profitability of multinational investment. A major goal is to specify the constraints imposed by "real" capital mobility (here I refer to FDI versus shorter-term capital movements such as portfolio investment) on the prospects for increased living standards and increased equality for women. A second, more theoretical goal, is to investigate the extent to which viewing multinational investment through a gender lens will yield significant insights into the behavior of MNCs and FDI.

Such a focus is important for both developing and developed countries. MNC investment has been a significant factor in the economic development of a small but important group of countries in the last several decades, primarily in East and Southeast Asia and in parts of Latin America and the Caribbean, where MNCs have also been large employers of women in the manufacturing sector. 
Perhaps even more importantly, an MNC-based strategy of development has become a central part of the neo-liberal model. For a decade or more, many developing countries have made the attraction of FDI a central part of their plans for economic growth. With the recent global financial crisis and growing appreciation of the potential instability of portfolio investment, FDI-based strategies may become even more popular.

In the first section I briefly discuss the empirical relationship between women's employment and MNCs in developing countries. In the second section I present a simple structuralist macroeconomic model, investigating wages and employment as a function of aggregate demand, capital mobility and labor supply. In section III I develop the central analytical contribution of this article, drawing women's roles in the household and family structure into the model of section II, where gender relations become a primary determinant of investment and macroeconomic outcomes. And in section IV I explore the effects of three policies: an increase in aggregate demand, a decline in gender wage discrimination, and an increase in women's productivity in the market, concluding with some general observations about the interaction between women's power in the family and the ability of countries to attract and retain multinational capital.

\section{Women's Employment and Foreign Direct Investment}

MNCs have been increasing in importance in developing countries in recent decades, but are very concentrated in certain countries and developing regions, especially Asia, parts of Latin America, and the transition economies of Eastern Europe. Manufacturing is the largest single component of international production - 16 percent of the world's manufacturing output was produced 
under the auspices of companies operating in countries other than their own in 1990, about a 40 percent increase over the share in 1977 (Lipsey 1998).

One of the more important factors in recent FDI growth is the international liberalization of services. One would expect more FDI in this sector because services are more difficult to trade, but technological change makes such a generalization problematic. An example is the recent growth in the long distance provision of back office services, beginning with simple data entry in the 1980s and now including services such as customer call services, hotel reservations, credit card authorizations and remote secretarial services. Information technology is another area experiencing high growth in international trade. Developing countries are a significant source service exports. In 1996, 24.9 percent of world exports in services came from developing countries with the lead taken by Hong Kong and Singapore (UNCTAD 1998).

Within manufacturing, there are behavioral and structural differences between MNCs that are export-oriented and those for which sales are mainly local (Caves 1996; Lipsey 1999), so it makes sense to differentiate between the two. And although the relationship between women's employment and MNCs is not well documented, there is strong evidence that the share of female employees in the labor-intensive, export-oriented assembly and multinational manufacturing sector is high (Joekes and Weston 1994; UNCTC/ILO 1985), so the types of multinational on which I focus in this paper are those in the exportoriented sector that employ mostly women.

One of the reasons that these relationships are difficult to gauge is because of the increasing prevalence of subcontracting and domestic outwork, jobs which are often directly connected to specific multinational companies via local 
intermediaries, weakening the distinction between foreign and local ownership (Ward and Pyle 1995).

As in other areas of production, these labor markets are segmented by gender. Women tend to be concentrated in electronics, textiles and garments, where low labor costs are a crucial part of international competitiveness (Starnberg Institute 1989; UNCTC/ILO 1988). Why do these multinationals prefer to hire women? As Elson and Pearson (1981) so aptly pointed out, one must consider how unit labor costs differ. First, women's wages are typically lower than men's, and employers perceive women as more "productive" in the types of jobs available in the export sector. Reasons that employers cite for the latter include: women's putative "nimble fingers;" their obedience and being less prone to worker unrest; their being suited to tedious work; and their reliability and trainability relative to men (Anker and Hein 1985; Elson and Pearson 1981; Fernández-Kelly 1983; Lin 1985). Similar reasoning could be applied to the "pink collar" aspects of the international production of services.

Although the modal worker of an export-oriented multinational is widely thought of as a young unmarried woman, there are some differences by industry and region. Women working in the electronics industry tend to be younger, while women working in textiles and garments tend to be older and are more likely to be married (Fernández-Kelly 1983; Lim 1990; Safa 1990, 1995; UNCTC/ILO 1985). From a regional perspective, women in Asian export processing zones tend to be younger and are less likely to be mothers than in Latin American and Caribbean export processing zones (Baden and Joekes 1993; Lim 1990). 
What about wages? Empirical studies of developing countries have indicated a positive correlation between wages (sometimes measured as per capita incomes) and various measures of FDI (Aitken, Harrison and Lipsey 1996; Lipsey 1999; Paus and Robinson 1998). But evidence of the connection between employment or net exports and per capita incomes is not as clear (Lipsey 1999), lending empirical credence to the finding that wages do matter for exportoriented and/or labor-intensive multinationals, the types most likely to employ female labor. So while multinational investment can bring about wage increases due to the upward pressure on labor demand, labor costs remain an important determinant of employment and export competitiveness, leading to a potentially contradictory dynamic between wage growth and the expansion of employment. This is perhaps one reason that industries dependent on low cost labor tend to employ women - an important issue to consider when thinking about the conditions under which economic growth can promote gender equality.

\section{A Simple Macroeconomic Model}

In this section I present a simple structuralist model of the macroeconomy, drawing on a long list of similar models in the structuralist literature (Taylor 1991; Marglin and Bhaduri 1990; Bowles and Boyer 1995; Gordon 1995; Blecker 1989; Epstein 1997). In these models, aggregate demand and the distribution of income play a central role in investment and consumption. Mine is an unabashedly simplified version, pared down to illustrate how changes in the degree of international capital mobility and aggregate demand affect women's wages and employment. The model illustrates the constraints facing domestic efforts to improve the conditions of women and families. ${ }^{1}$ 
In addition to gender dynamics, I will emphasize the effects of "real" capital mobility - the mobility of investment that is directly employmentgenerating. ${ }^{2}$ Although a motivation for this article is export-oriented foreign direct investment in particular, this focus on real capital mobility means that the reasoning applies to both domestic and foreign investment, with the latter significantly more mobile than the former.

Why does capital mobility increase? The most common reason stressed by mainstream economists is technology, such as reductions in communications and transport costs. Equally important but less discussed are changes in institutional and political structures. Stronger domestic and international enforcement structures, such as international investment treaties and the proposed Multilateral Agreement on Investment, can enhance capital mobility. Institutional innovations such as laws that spell out the rights and responsibilities of firms are costly to create and enforce, and as a result they are more likely to arise when large profits, sufficient to overcome the uncertainties and high fixed costs of investing, are forthcoming.

The opening up of new, stable, low-wage countries to MNCs can therefore play an important role in actually enhancing capital mobility (Braunstein and Epstein 1999; Epstein and Gintis 1995). When large unit labor cost differentials open up between countries, MNCs have strong incentives to create the channels and institutional structures that make foreign direct investment possible. Here then is a way that gender can actually contribute directly to increased capital mobility because gender-based wage differentials enhances incentives for firms (and countries) to create the institutional environment necessary for FDI. 
It is important to note, however, that several factors can counter the tendencies toward increased capital mobility. One is so-called agglomeration effects: economies of scale and scope that derive from proximity. Second and third, many studies show that infrastructure investment can also be an attractive draw for MNCs as can a large domestic market (Caves 1996). In this paper, since I am focusing on MNCs in developing countries that specialize in export, local demand factors will not compensate for declines in profitability. However, agglomeration and infrastructure effects remain relevant.

\section{A. The Demand Side}

The context for this analysis is a semi-industrialized economy with two industrial sectors that are gender typed: a female labor-intensive export sector that is also the destination of foreign direct investment, and a domestic goods sector that only employs men. Agriculture, informal employment and the nonmarket sector are all implicitly potential alternatives to formal sector employment, a factor more explicitly discussed in section III.

The structure of the model follows that by Marglin and Bhaduri (1990); it is presented in summary form in table one. National income (or output) is split between capitalists who receive profits and workers who receive wages; I make an additional differentiation between male and female market labor. The distribution of national income is represented as shares: profit's share of income is represented by $\pi, f$ is female labor's share, and $m$ is male labor's share, as indicated in equation (1.1). Deriving the profit rate is merely a matter of accounting, and is formally derived in equation (1.2). <TABLE ONE HERE.>

Equation (1.3) indicates that the growth of investment normalized by the capital stock depends partly on the profit rate, ${ }^{3}$ which is in turn determined by 
profit share and capacity utilization, and partly on the extent of international capital mobility, measured by the degree of financial openness $(\sigma, 0 \leq \sigma \leq 1)$ times the profit rate abroad $\left(r^{*}\right)$. This measure of international capital mobility indicates the responsiveness of investment (both domestically and foreignsourced) to the domestic profit rate relative to the foreign profit rate, and it affects the system by heightening investment sensitivity to changes in the domestic profit rate brought about by changes in profit share. Increases in both profit share and capacity utilization induce more investment; assuming that capital mobility is greater than zero, an increase in the foreign profit rate induces a decline in domestic investment. (Signs for first partial derivatives are noted above each variable.)

The growth of savings normalized by the capital stock depends on the marginal propensities to spend by capital and labor and on net exports as indicated in equation (1.4). A key assumption is that the marginal propensity to consume out of wages is greater than the marginal propensity to consume out of profits (capital saves more than workers). As a result, an increase in the profit share raises savings, as does an increase in output. Conversely, an increase in net exports reduces total savings available since $S-N X=I{ }^{4}$

On the demand side, equilibrium means that the growth rate of capital desired by investors equals that desired by savers, and the result is named after a close cousin in standard textbooks, the IS schedule (1.5). Its slope in $(z, \pi)$ space is represented by equation (1.6). The partial derivatives in (1.6) have all been discussed above with the exception of the partials for net exports with respect to output and profit share. By assumption, import demand rises with capacity 
utilization and so movements in net exports and output are inversely related. Profit rates measure international competitiveness; capitalists cannot pass on wage increases via higher prices because of international competition in export markets. Hence profit shares and net exports move in the same direction although the relationship is not a causal one. ${ }^{5}$

The main issue on the demand side is whether the IS curve is upward or downward sloping - whether declines in profit share are associated with declines or increases in output (see figure one). <FIGURE ONE ABOUT HERE.> These relationships are determined by the sign of (1.6) in table one. We can assume that the numerator is negative because stability requires that at the margin, savings is more responsive to changes in capacity utilization than output $\left(s_{z}>i_{z}\right)$, and the subtraction of the net exports term makes the numerator a larger negative number. Looking at the denominator and setting aside the issue of net exports, if $s_{\pi}>i_{\pi}$ then the numerator and denominator are of the same sign and the IS curve is downward sloping. If, however, $i_{\pi}>s_{\pi}$, the denominator is positive and the IS curve is upward sloping. The subtraction of the net exports term in the denominator makes it more likely that the IS slope is positive, so an economy open to trade in this manner is more likely to exhibit a positive correlation between profit share and output.

The central contrast in this article is between two different regimes - the cases of high and low capital mobility. The degree of capital mobility affects investment's sensitivity to changes in profit because if the profit share falls, inducing a fall in the profit rate, then investment may decline more than in the absence of investment opportunities abroad because the opportunity cost of 
continuing to invest in the particular country goes up when alternatives to domestic investment are an option. In terms of equation (1.6), this effect is reflected by increasing the value of $i_{\pi}$.

Referring back to figure one, a downward sloping relationship is the low capital mobility (LCM) case - when an increase in wages is associated with more economic activity because the increase in consumer demand brought about by an increase in the wage share outweighs the decline in investment demand brought about by the decline in profits. Put another way that emphasizes the degree of capital mobility - because investment has few outside options, responsiveness to changes in profit share is very low (the value of $i_{\pi}$ is low). A positive sloping relationship indicates the high capital mobility $(\mathrm{HCM})$ case where an increase in wages (decline in the profit share) reduces investment more than it raises consumption and thereby lowers the level of economic activity. The reasoning is the opposite of that posed in the LCM case - when investors have easy access to outside options, small declines in profit share sends capital elsewhere ( $i_{\pi}$ is high).

\section{B. The Supply Side}

The next relationship to be determined is the supply side of the model, referred to throughout this discussion as the producer's equilibrium (PE). The PE is determined by structures and relations both in the product and labor markets. The product and labor markets of this economy have two distinct sectors: the domestic goods sector that employs men and the multinational export sector that employs women. For the purposes of this discussion, changes in the economy-wide wage share and total employment are generated solely by 
changes in female wages and employment. ${ }^{6}$ The supply side of the model is summarized in table two.

<TABLE TWO ABOUT HERE.>

Consider first the product market. When nominal wages change, product market factors determine the extent to which these changes are passed on in the form of higher (or lower) prices. My focus is on the multinational export sector where there is an extremely competitive environment and wage changes cannot be easily passed on to consumers. Therefore, profit shares move in response to wage changes, and the firm's options in this context are limited to deciding on whether to maintain, reduce, expand or upgrade production in the locale. Equation (2.1) represents these relationships. International prices $\left(P_{x}\right)$ are constant due to international competition, and labor productivity (output $/$ women's market hours $=q$ ) is assumed constant as well. So it is the female wage $\left(w_{f}\right)$ and capital's markup over unit cost $(\tau)$ that vary.

In the labor market, the effects of increases in women's employment on wages can be mediated by institutions both in the labor market and the household. Labor market institutions such as unions can take advantage of tight labor markets by translating increased bargaining power vis-a-vis capital into higher wages (Carlin and Soskice 1990). But these institutions are systematically weaker for women, especially in industries that face substantial international competition. As a result, labor market conditions represented in the producer's equilibrium reflect how gender is constituted in the household. Equation (2.2), which indicates that women's wages are positively correlated with the level of employment, is an aggregate representation of the female reservation wage as it 
is determined by women's productive and social roles outside the formal market sector. The precise nature of this relationship is more complex than this simple equation suggests; more will be said about this in the next section.

The PE function combines equations (2.1) and (2.2) and can be written as in equation (2.3), where export prices are normalized to one and the markup is written in terms of the profit share for consistency with the terms of the IS curve. The formula for its slope is written in (2.4). Under these assumptions, the PE function is a downward sloping curve.

\section{Family Structure and Female Labor Supply}

Macroeconomists and development economists have not paid enough attention to the unique factors affecting female labor supply, tending to overlook how workers' productive roles outside the factory door, and the institutional and social contexts in which they live, create fundamental differences between the labor supply behavior of women and men. Specifically, they ignore factors affecting the productivity of nonmarket work, including fertility and urbanization; institutional factors such as educational access, the public provision of childcare and enforcement of child support responsibilities; and bargaining and inequality in the household.

These factors affect women's labor supply in complex ways. Fertility decline has been accompanied by an increase in women's labor force participation (Easterlin 1989); high incidences of male desertion and non-marital births probably lower women's reservation wages; increases in female education raise the reservation wage of young women who remain in school longer and change the composition of the female labor force. Women with little power in the family may be barred from entering the labor market by husbands who fear 
the loss of their own bargaining power as wives gain financial independence (Braunstein and Folbre 1999).

In this section, I will experiment with filling out this gap by incorporating into the producer's equilibrium women's economic alternatives to working in the multinational sector and their autonomy within the family. The reader is reminded that this is a theoretical exercise - the focus will remain on developing the workings of the model as the empirical foundation for the various female labor supply regimes has been covered elsewhere (Braunstein 1999). The PE curve will now reflect two dimensions.

The first dimension measures the extent to which women and men share the costs of reproduction at the household level, or, put another way, the cohesiveness of family structure. At one extreme is the family form "patriarchal presence." It parallels what in the anthropological literature has been identified as systems of household organization centered around the conjugal bond, and embedded in cultural rules that prescribe male authority over as well as responsibility for the protection and provisioning of women and children. Patriarchal presence also exhibits traditions of patrilineal descent and inheritance and often espouses strong pro-natalist norms (Kabeer 1994: 115). Men's economic responsibility for the family is paralleled by their decisionmaking power within the family. Its clearest instances are found in geographical areas that include North Africa, the Muslim Middle East, and South and East Asia (Kandiyoti 1991: 107-108). These factors would lead one to expect a high reservation wage for mothers. Conversely, elder daughters whose economic value to the male household head may be relatively low are easily sent out to work in the market. The early years of East Asia's export development in the 
1960s and 1970s provide an example of how patriarchal presence can affect female labor supply. Strong traditions of authority based on gender and age put the male household head in the position of decisionmaking for the extended household; the low economic value accorded to daughters by the patriarchal head thus provided a deep pool of low-cost labor for expanding export sectors.

At the other extreme are families where women bear a substantial proportion of the time and money costs of raising families on their own - what I term families maintained by women alone. The weaker conjugal ties found in the Caribbean, parts of Latin America and Sub-Saharan Africa fall into this category. Families maintained by women alone can be thought of as the mirror image of those exhibiting patriarchal presence, with the added and important caveat that these households typically face more dire economic circumstances. An exception is the class of households where women have access to assets with which to farm or run a business, as in much of Sub-Saharan Africa. Reliable data on households maintained by women alone is hard to come by because much is based on census data, which varies in definition and quality country by country (Chant 1997; Folbre 1991).

In the developing world, the majority of households maintained by women alone is the result of the prevalence of widowhood, desertion and migration. In Latin America and the Caribbean, unmarried parenthood is a significant factor. In the Caribbean, for example, two-thirds of all births take place outside of official marriage (Chant 1997: 85). In Northern Mexico, the flow of male migrants to the U.S. has contributed to increases in female-headed households (Chant 1997: 91). In terms of reservation wages, where women have access to their own income outside the multinational sector, we would expect 
women's autonomy to be consistent with a higher reservation wage. Where household headship also confers a high degree of economic risk, reservation wages will remain low for a larger subset of women than in areas where most households are headed by men, expanding the pool of cheap female labor available to MNCs. So while female headship may confer decisionmaking power to women, the resulting income constraints can become a primary determinant of the reservation wage.

The second dimension of the PE curve is defined relative to multinational capital and describes women's alternatives to working in the multinational sector - it is measured as a reservation wage, high $(\mathrm{H})$ versus low $(\mathrm{L})$. Put together with the first dimension which has been defined relative to family structure patriarchal presence $(\mathrm{P})$ versus families maintained by women alone $(\mathrm{M})$, there are four possible PE regimes as shown in table three.

HM corresponds to developing areas where family structure has afforded women some autonomy from men in the household but they also have economic opportunities outside the industrial sector, such as in Sub-Saharan Africa where women have access to income-earning assets such as land. LM reflects a different type of autonomy in that women who are maintaining families alone have few alternatives to seeking jobs in export factories, as in the Caribbean and Northern Mexico. HP is consistent with areas where men keep their wives and / or daughters at home as in parts of the Muslim Middle East, and LP corresponds to those areas where men maintain their power in the family but women (mostly daughters) are sent out to work in the export sector as in parts of East Asia. These examples also make clear how the dimensions may affect one another - an HP regime can become an LM regime when in a context of long- 
term economic hardship men can no longer fulfill their economic responsibilities to the family, as has been one of the results of structural adjustment in Mexico (Benería 1992).

\section{<TABLE THREE ABOUT HERE.>}

Export-oriented foreign direct investment tends to go to LM and LP locations because of the availability of low-cost labor. HP locations can become LP locations when subcontracting in the form of industrial homework is introduced, so even in situations where male heads prefer their wives to stay at home, wives' reservation wages for homework might be very low while those for wage employment outside the home are still high. Moreover, HP and LP locations can co-exist, such as was the case in East Asia where daughters were sent to work in the new export-oriented sector but traditions of male authority in the household and son-preference were maintained (Greenhalgh 1988; Salaff 1981). In the next section, I will focus on two PE regimes that correspond to these types of locations for export-oriented multinational activity: LM (corresponding to parts of Latin America and the Caribbean) and HP/LP (corresponding to parts of East and Southeast Asia).

\section{Gender Regimes and Public Policy}

Putting the IS and PE curves together, figure 2a represents an interaction between the demand and supply sides of the model, illustrating the case of low capital mobility by the downward-sloping IS curve and the two types of PE curves (patriarchal presence with a low reservation for daughters and a high reservation for mothers (HP/LP), and families maintained by women alone with a low reservation wage (LM)). Figure 2a also shows the impact on employment and wages of increases in investment resulting from growing external aggregate 
demand. <FIGURE TWO HERE.> I have drawn the LM and HP/LP curves as starting out at the same $(\pi, z)$ equilibrium for comparison. (An algebraic derivation of all the comparative statics in this section are presented in the appendix.)

In the LM case, this positive shift in aggregate demand does not affect the wage share very much (if at all), but there is some increase in output, represented by the movement from $z_{0}$ to $z_{1}^{m}$. Enhancing women's economic security through government supports (steepening the LM curve) is good for women and output. In the patriarchal case, there is an increase in the wage share $\left(\pi_{0}\right.$ to $\left.\pi_{1}^{p}\right)$ and in total output $\left(z_{0}\right.$ to $\left.z_{1}^{p}\right)$, both of which are greater than in the LM case, the reason being that women's reservation wages are higher in the patriarchal case. Since wages and capacity utilization move together, the higher the wage share, the greater is national income.

This comparative analysis between the LM and HP/LP cases rests on the presumption that labor demand in the HP/LP case is high enough to overstep the bounds of the pool of low-cost daughters. Labor shortages have been a factor in the history of some of the East Asian countries, such as Taiwan in the 1970s and to a lesser extent South Korea in the late 1980s (Brinton, Lee and Parish 1995). But cultural shifts such as the increased age of marriage that tends to accompany the paid employment of young women, and changes in the organization of production such as the satellite factory system in Taiwan that made industrial work more consistent with the traditional female roles of wife and mother (Hsiung 1996), can counter the upward pressure on wages. 
It is interesting to consider the effects of subcontracting in the case of low capital mobility as well. Subcontracting, via lowering women's reservation wages due to the heightened complementarity between market and nonmarket work and the increased difficulty of organizing, flattens the PE curves. In both cases, this results in an increase in profit share with declines in total output. So in a low capital mobility regime, subcontracting is bad for women and the economy.

Figure $2 \mathrm{~b}$ illustrates the same aggregate demand effects in the case of high capital mobility, only this time the shift is posited as the result of an increase in world aggregate demand. ${ }^{8}$ The shift out of the HCM curve has effects similar to the low capital mobility case in the sense that employment and wages increase for both LM and HP/LP regimes. But the relative performance of the two regimes are the reverse of the low capital mobility case. The LM regime enjoys greater increases in output than the HP/LP regime because wages do not increase as much $\left(z_{1}^{m}>z_{1}^{p}\right)$; openness affords capital more options when faced with wage increases. Subcontracting, which would flatten either PE curve, increases both profit share and output, the opposite result for overall economic activity than in the low capital mobility case.

An increase in women's wages relative to men's (a decline in gender discrimination) is represented by a shift downward in the PE curve. In the low capital mobility case as drawn in figure 3a, policies that improve women's relative wages can increase output and employment because of increased demand for domestic products. ${ }^{9}<$ FIGURE THREE HERE.> Increases in output and women's wages are greater in the HP/LP case than the LM case because 
women's wages increase at a faster rate in the former than the latter, so the wage share goes up by more, as does output in line with consumer demand movements outweighing declines in investment demand.

Figure $3 \mathrm{~b}$ shows a decline in gender discrimination in a context of high capital mobility, which in both the HP/LP and LM cases leads to lower levels of employment and output, even if all of the increased income from women's higher relative wage is spent in the home country. The problem is the increased mobility of capital and the decline in multinational investment as local wages increase. The resulting loss of output and employment is greater for the LM ( $z_{0}$ to $z_{1}^{m}$ ) than the HP/LP regime $\left(z_{0}\right.$ to $\left.z_{1}^{p}\right)$ because the female reservation wage is more responsive to changes in labor demand in the case of patriarchal presence.

One way to increase wages and employment in the high capital mobility case is by adopting policies that raise women's labor productivity, such as funding for education and training. Figure 4 shows the shift up in the PE curves resulting from productivity increases. Here, more investment is attracted from abroad, generating more employment, most significantly in the LM case because the added labor demand does not result in the same upward pressure on wages as in the patriarchal case. According to this model, then, raising women's productivity, through increases in education and skill, may be a more effective policy for creating jobs than reducing gender discrimination in a situation of high capital mobility.

Contrasting the cases of low and high capital mobility suggests some themes relative to women's autonomy in the household versus the labor market and the effectiveness of various social policies. Beginning with the low capital 
mobility case, we have seen that changes in domestic aggregate demand and reductions in discrimination benefit economies characterized by all types of household structures in terms of women's wages, employment, and output, but that the case with patriarchal presence enjoys greater overall improvements (figures 2a and 3a). Subcontracting only results in increasing capital's profit share for all gender regimes; total employment and output decline.

In light of these conclusions, one could say that in a context of low capital mobility, increases in women's bargaining power relative to capital (reflected in shifts down and/or increases in the slope of the PE curve), are good for women and the economy in terms of wages and employment. But if increases in women's autonomy in the household make them more dependent on the multinational sector for economic support, it may lead to declines in output and wage share. Thus, in the context of a relatively closed economy with little capital mobility, regimes characterized by cohesive family structures perform better than those with a high percentage of families maintained by women alone in terms of aggregate output and wage shares.

In the case of high capital mobility, changes in global aggregate demand or an upgrade in women's skills (figures $2 \mathrm{~b}$ and 4 ) benefit both HP/LP and LM cases, but it is the latter that enjoys greater improvements than the former, the opposite of the low capital mobility case. The basic reasoning is that wages rise faster in the HP/LP case because women are not so beholden to the multinational sector for family support. Both gender regimes suffer losses in output (but improvements in the wage share) when anti-discriminatory rules are enforced, although the case of families maintained by women alone will suffer a greater loss in output to the extent that the aggregate reservation wage changes 
only by the amount of the wage increase, as depicted in figure $3 \mathrm{~b}$.

Subcontracting causes a decline in the wage share and an increase in output for both cases, the converse of the low capital mobility case in terms of employment outcomes.

In sum then, in the case of high capital mobility, increases in women's bargaining power relative to capital (shifts down or a steeper slope of the PE curve) tend to result in declines in output, but increases in women's autonomy from men (a flattening of the PE curve) may be good for output. So in an open economy setting, economies stand to gain in terms of national income by challenging male power in the household, but bargaining with capital may prove a more hazardous path.

Subcontracting offers a way out for both men and capitalists in the high capital mobility case by cheapening women's labor (flattening the PE curve) without sacrificing male authority. Perhaps this is one of the reasons that subcontracting and homework have been an increasingly dynamic element in internationalized production. International labor rights and standards become extremely important here because it is the only way that women can gain relative to capital in individual economies without sacrificing output.

\section{Further Research}

By integrating household-level factors that affect the female reservation wage with those that prevail in the labor market and the macroeconomy, this article offers a theoretical framework for analyzing the relationship between foreign direct investment, international capital mobility and gender in developing economies. What is clear, from a theoretical perspective at least, is that gender relations can affect the profitability of investment via their impact on 
the female reservation wage. This work also suggests in what contexts female autonomy may be consistent with attracting and/or retaining multinational capital. In future research I intend to empirically investigate this relationship, testing whether one can establish a correlation between international capital flows and family structure.

The mobility of various types of MNCs also requires more analysis. The growing importance of services in foreign direct investment could detract from the average mobility of international capital since one expects services to be delivered in situ. But the main issue in this article is the type of FDI that generates employment for women, and what types of services typically employ female labor is still an open question - certainly there are particular classes of more labor intensive services that focus on export. So the question of what types of industries or sectors are more mobile than others becomes one of whether these same industries are more or less likely to employ female labor, an important issue to understand when considering policies that link international capital with the potential to enhance women's well-being. 


\section{Endnotes}

${ }^{1}$ See Blecker and Seguino (1998) for another structuralist model that incorporates gender relations and Braunstein and Hertz (1998) for another macroeconomic approach to the genderwage gap and trade.

${ }^{2}$ There is no financial sector in this model, so when discussing investment I refer to only that which directly generates employment.

${ }^{3}$ This should really be the expected profit rate, but since expected profit rates and actual profit rates move together, I use the latter as a measure of the former.

${ }^{4}$ I assume no government deficit or surplus for notational simplicity.

${ }^{5}$ The impact of changes in output and profit share on net exports is really an empirical question there are good arguments that these signs run the other way. For instance, in an export-oriented economy, one might expect that increases in output induce a bigger expansion of exports than imports, resulting in a positive correlation between capacity utilization and net exports. Because the main division in this discussion is between the cases of low and high capital mobility, changes in the net exports term merely steepen or flatten the slope, so its effects are of magnitude, not direction. For more discussion, see Braunstein (1999); for an extensive treatment of the issue of trade in a structuralist model, see Blecker (1989).

${ }^{6}$ Assumptions about the male sector include the following: the product market is characterized by fixed markups and productivity - wage changes are matched by price changes, and so profit share and male wage share remain constant. In the labor market, male wage increases are driven by declines in their unemployment rates owing to labor market bargaining institutions. The resulting economy-wide PE curve is then posited as a weighted average of the male and female sectors, with changes in the male sector only resulting in changes in the vertical placement of the PE curve. A more detailed analysis is available in Braunstein (1999).

${ }^{7}$ This section is based on other work in which I develop an intra-household bargaining model to specify family structure (Braunstein 1999). 
${ }^{8}$ Policies to increase domestic demand are unlikely to benefit women as much because any attempt to increase wages as a result will lead to reductions in multinational investment as local wages increase.

${ }^{9}$ For a similar result, see Blecker and Seguino (1998). 


\section{References}

Aitken, Brian, Ann Harrison and Robert E. Lipsey. 1996. "Wages and Foreign Ownership: A Comparative Study of Mexico, Venezuela, and the United States." Journal of International Economics (40): 345-371.

Anker, Richard and Catherine Hein. 1985. "Why Third World urban employers usually prefer men." International Labour Review 124(1): 73-90.

Baden, Sally and Susan Joekes. 1993. "Gender Issues in the Development of the Special Economic Zones and Open Areas in the People's Republic of China." Paper prepared for presentation at Fudan University seminar "Women's Participation in Economic Development," Shanghai, People's Republic of China, April.

Benería, Lourdes. 1992. "The Mexican Debt Crisis: Restructuring the Economy and the Household," in Lourdes Benería and Shelley Feldman (eds.) Unequal Burden: Economic Crises, Persistent Poverty, and Women's Work. Boulder, CO: Westview Press.

Benería, Lourdes and Shelley Feldman (eds.) 1992. Unequal Burden: Economic Crises, Persistent Poverty, and Women's Work. Boulder, CO: Westview Press.

Blecker, Robert. 1989. "International Competition, Income Distribution and Economic Growth." Cambridge Journal of Economics 13(3): 395-412.

Bowles, Samuel and Robert Boyer. 1995. "Wages, Aggregate Demand, and Employment in an Open Economy: An Empirical Investigation," in Gerald Epstein and Herbert Gintis (eds.) Macroeconomic policy after the conservative era: Studies in investment, saving and finance. Cambridge, New York and Melbourne: Cambridge University Press.

Braunstein, Elissa. 1999. "Engendering Globalization: Household Structures, Female Labor Supply and Growth. Three Essays." PhD Dissertation, University of Massachusetts, Amherst.

Braunstein, Elissa and Gerald Epstein. 1999. "Creating International Credit Rules and the Multilateral Agreement on Investment: What are the Alternatives?" in John Grieve Smith and Jonathan Michie (eds.) Global Instability. The Political Economy of World Economic Governance. London and New York: Routledge Press.

Braunstein, Elissa and Nancy Folbre. 1999. "To Honor and Obey: The Patriarch as Residual Claimant." University of Massachusetts, Amherst, Department of Economics.

Braunstein, Elissa and Thomas Hertz. 1998. "A Gendered Dynamic Model of Export-Led Growth." Paper prepared for the Allied Social Science Meetings, Chicago, January 3-5. 
Brinton, Mary C., Yean-Ju Lee, William L. Parish. 1995. “Married Women's Employment in Rapidly Industrializing Societies: Examples from East Asia." American Journal of Sociology 100(5): 1099-1130.

Cagatay, Nilufer, Diane Elson and Caren Grown (eds.) 1995. Gender, Adjustment and Macroeconomics. World Development 23(11).

Carlin, Wendy and David Soskice. 1990. Macroeconomics and the Wage Bargain. New York: Oxford University Press.

Caves, Richard. 1996. Multinational Enterprise and Economic Analysis. Cambridge: Cambridge University Press.

Chant, Sylvia. 1997. Women-Headed Households. Diversity and Dynamics in the Developing World. New York: St. Martin's Press.

Easterlin, Richard . 1989. "Fertility," in John Eatwell, Murray Milgate, and Peter Newman (eds.) Social Economics. New York: The Macmillan Press Limited.

Elson, Diane (ed.) 1991. Male Bias in the Development Process. Manchester: Manchester University Press.

Elson, Diane and Ruth Pearson. 1981. “Nimble Fingers Make Cheap Workers: An Analysis of Women's Employment in Third World Export Manufacturing." Feminist Review 7: 87- 107.

Epstein, Gerald. 1997. "Central Banking," in Robert Pollin (ed.) The Macroeconomics of Saving, Finance and Investment. Ann Arbor: University of Michigan Press.

Epstein, Gerald and Herbert Gintis (eds.) 1995. Macroeconomic policy after the conservative era: Studies in investment, saving and finance. Cambridge; New York and Melbourne: Cambridge University Press.

Fernández-Kelly, Maria Patricia. 1983b. For We are Sold, I and My People: Women and Industrialization in Mexico's Frontier. Albany: SUNY Press.

Folbre, Nancy. 1991. "Women on Their Own: Global Patterns of Female Headship," in Rita S. Gallin and Anne Ferguson (eds.) The Women and International Development Annual Volume 2. Boulder: Westview Press.

Gordon, David M. 1995. "Growth, Distribution, and the Rules of the Game: Social Structuralist Macro Foundations for a Democratic Economic Policy," in Gerald Epstein and Herbert Gintis (eds.) Macroeconomic policy after the conservative era: Studies in investment, saving and finance. Cambridge; New York and Melbourne: Cambridge University Press. 
Greenhalgh, Susan. 1988. "Intergenerational Contracts: Familial Roots of Sexual Stratification in Taiwan," in Daisy Dwyer and Judith Bruce (eds.) A Home Divided: Women and Income in the Third World. Stanford, CA: Stanford University Press.

Hsiung, Ping-Chun. 1996. Living Rooms as Factories: Class, Gender, and the Satellite Factory System in Taiwan. Philadelphia: Temple University Press.

Joekes, Susan and Ann Weston. 1994. Women and the New Trade Agenda. New York: UNIFEM.

Kabeer, Naila. 1994. Reversed Realities: Gender Hierarchies in Development Thought. London and New York: Verso.

Kandiyoti, Deniz. 1991. "Bargaining with Patriarchy." in Judith Lorber and Susan A. Farell (eds.) The Social Construction of Gender. New Park, CA, London and New Delhi: Sage Publications.

Lim, Linda C. 1990. “Women's Work in Export Factories: The Politics of a Cause," in Irene Tinker (ed.) Persistent Inequalities: Women and World Development. Oxford: Oxford University Press.

Lin, Vivian. 1985. "Women Factory Workers in Asian Export Processing Zones," in Ernst Utrecht (ed.) Transnational Corporations in South East Asia and the Pacific. Volume VII. Transnational Corporations and Export-oriented Industrialization. Sydney, Australia: Transnational Corporations Research Project, University of Sydney.

Lipsey, Robert E. 1999. "The Location and Characteristics of U.S. Affiliates in Asia." NBER Working Paper 6876.

Lipsey, Robert E. 1998. “Internationalized Production in Developed and Developing Countries and in Industry Sectors." NBER Working Paper 6405.

Marglin, Stephen A. and Amit Bhaduri. 1990. "Profit Squeeze and Keynesian Theory," in Stephen A. Marglin and Juliet B. Schor (eds.) The Golden Age of Capitalism: Reinterpreting the Postwar Experience. New York: Oxford University Press.

Paus, Eva A. and Michael Robinson. 1998. "Globalization and Labor: The Impact of Direct Foreign Investment on Real Wage Developments, 19681993." Paper prepared for the XXI International Congress of the Latin American Studies Association, Chicago, September 24-26.

Safa, Helen I. 1995. The Myth of the Male Breadwinner: Women and Industrialization in the Caribbean. Boulder: Westview Press. 
Safa, Helen I. 1990. "Women and Industrialisation in the Caribbean," in Sharon Stichter and Jane L. Parpart (eds.) Women, Employment and the Family in the International Division of Labour. Philadelphia: Temple University Press.

Salaff, Janet W. 1981. Working Daughters of Hong Kong: Filial piety or power in the family? Cambridge: Cambridge University Press.

Seguino, Stephanie. 1997. "Gender Wage Inequality and Export-led Growth in South Korea." Journal of Development Studies 34(2): 102-132.

Starnberg Institute. 1989. “Working Conditions in Export Processing Zones in Selected Developing Countries." Prepared for the U.S. Department of Labor.

Standing, Guy. 1989. "Global Feminization through Flexible Labor." World Development 17(7): 1077-1095.

Taylor, Lance. 1991. Inflation, Stabilization and Growth. Cambridge: MIT Press.

United Nations Conference on Trade and Development. 1998. "Scope for expanding exports of developing countries in specific services sectors through all GATS modes of supply, taking into account their interrelationship, the role of information technology and of new business practices." Note by the UNCTAD secretariat. 24 July.

United Nations Centre on Transnational Corporations and International Labour Organisation. 1988. Economic and Social Effects of Multinational Enterprises in Export Processing Zones. Geneva: ILO.

United Nations Centre on Transnational Corporations and the International Labour Office. 1985. Women workers in multinational enterprises in developing countries. Geneva: ILO.

Ward, Kathyrn B. and Jean Larson Pyle. 1995. “Gender, Industrialization, Transnational Corporations, and Development: An Overview of Trends and Patterns," in Christine E. Bose and Edna Acosta-Belén (eds.) Women in the Latin American Development Process. Philadelphia: Temple University Press. 


\section{Table One • The Demand Side}

$\begin{array}{ll}\text { Distribution of National Income } & 1=\pi+f+m \\ \text { Profit Rate } & r=(R / K)=(R / Y)(Y / \bar{Y})(\bar{Y} / K)=\pi z a\end{array}$

Investment

Error! Objects cannot be created from editing field codes.

\section{(1.3)}

Savings

$g^{s}=S / K=s(\stackrel{+}{\pi}, \stackrel{+}{z}, \stackrel{+}{N X}(\stackrel{-}{\pi}, \vec{z}))$

Equilibrium (IS)

$g^{i}=g^{s}$

Slope of IS schedule

$$
\frac{d \pi}{d z}=-\frac{\left(\stackrel{+}{i_{z}-s_{z}^{-}-s_{N X}^{-} \frac{\partial-}{\partial N}}\right)}{\left(\stackrel{+}{i_{\pi}^{+}-s_{\pi}^{+}-s_{N X}^{-} \frac{\partial N X}{\partial \pi}}\right)}
$$

where

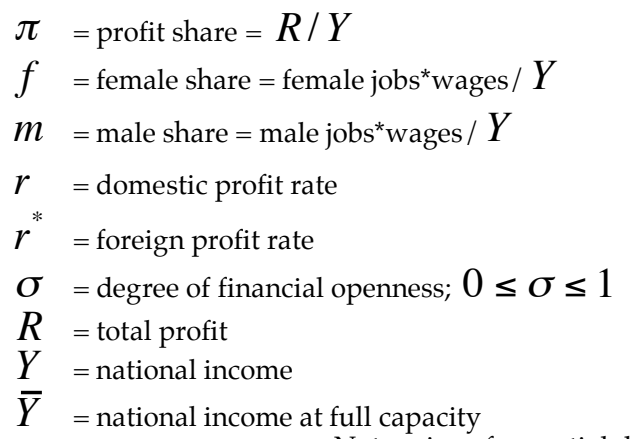

$K \quad=$ capital stock

$z \quad=$ capacity utilization $=Y / \bar{Y}$

$a \quad=$ full capacity output $/$ capital stock $=\bar{Y} / K$

$g^{i} \quad=$ growth rate of $\mathrm{K}$ desired by investors

$g^{s} \quad=$ growth rate of $\mathrm{K}$ desired by savers

$I \quad=$ investment

$S \quad=$ savings

$N X=$ net exports $=$ exports - imports

Note: signs for partial derivatives recorded above relevant variables. 


\section{Table Two • The Supply Side}

Product Market

Labor Market

Producer's Equilibrium (PE)

Slope of the PE schedule

$w_{f}=$ female wage

$P_{x}=$ (fixed) MNC good price

$\pi=$ profit share

$$
P_{x}=(1+\tau) \frac{w_{f}}{q}
$$

$w_{f}=w_{f}(\stackrel{+}{z})$

$\pi=1-\frac{w_{f}(z)}{q}$

$\frac{d \pi}{d z}=-\frac{w_{f z}}{q}$

where

$\mathrm{z}$ = capacity utilization

$\tau=$ MNC markup over cost

$q$ = female labor productivity 
Table Three • The PE Regime

family structure

P $\quad M$

reservation $\mathbf{H} \quad \mathrm{HP} \quad \mathrm{HM}$

wage $\quad$ L LP LM

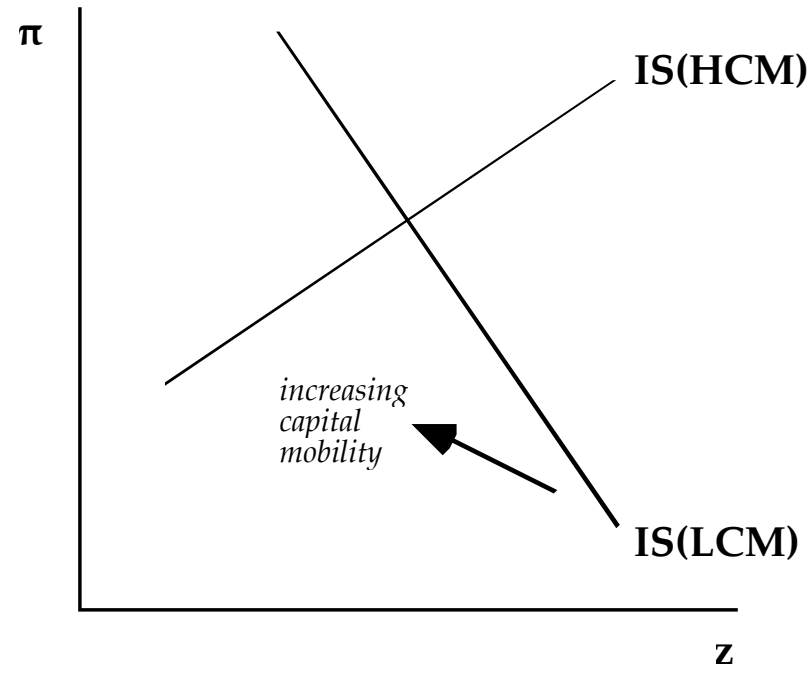

Figure 1: Goods market equilibrium and capital mobility 
Figure 2: An increase in aggregate demand

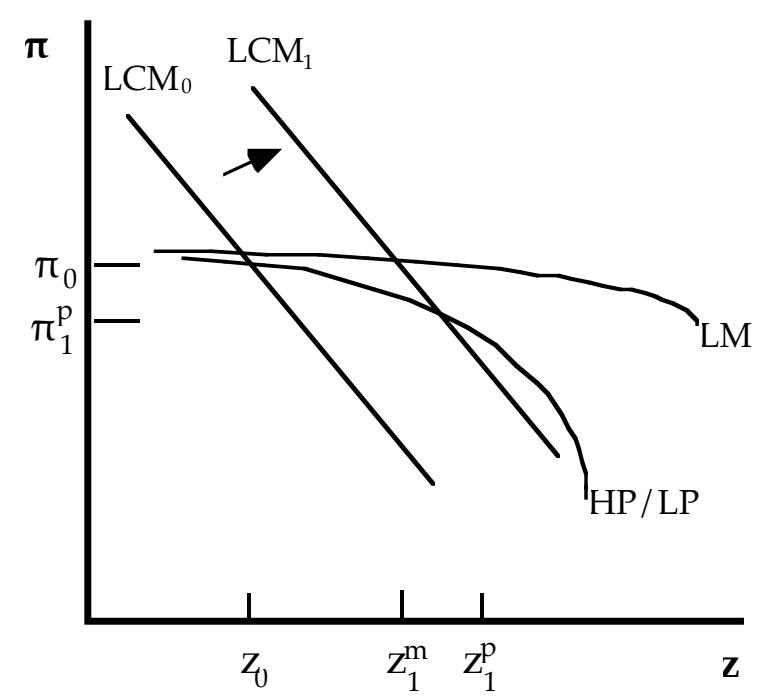

Figure 2a: Low capital mobility and an increase in aggregate demand

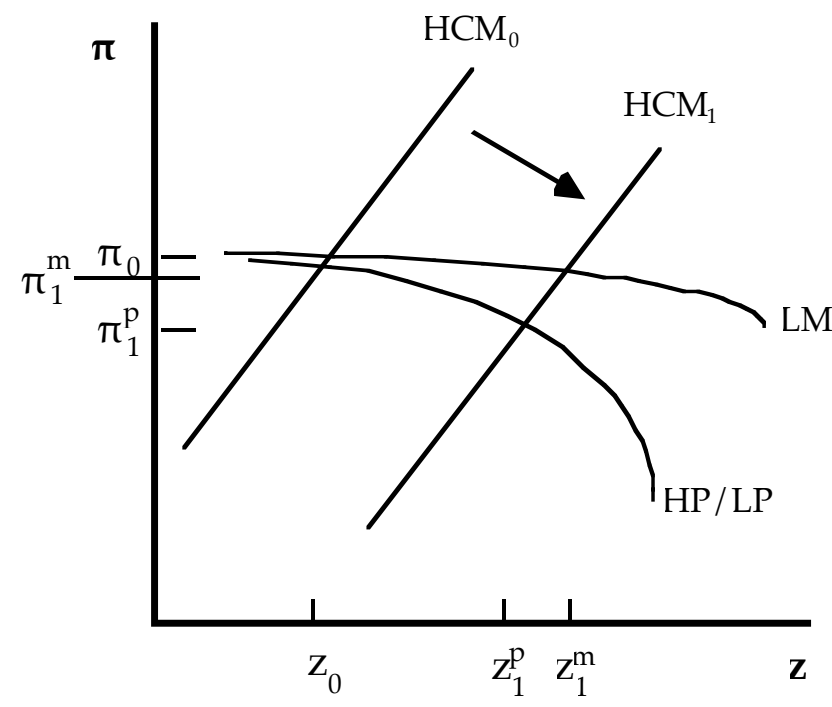

Figure 2b: High capital mobility and an increase in aggregate demand 
Figure 3: A decline in gender wage discrimination

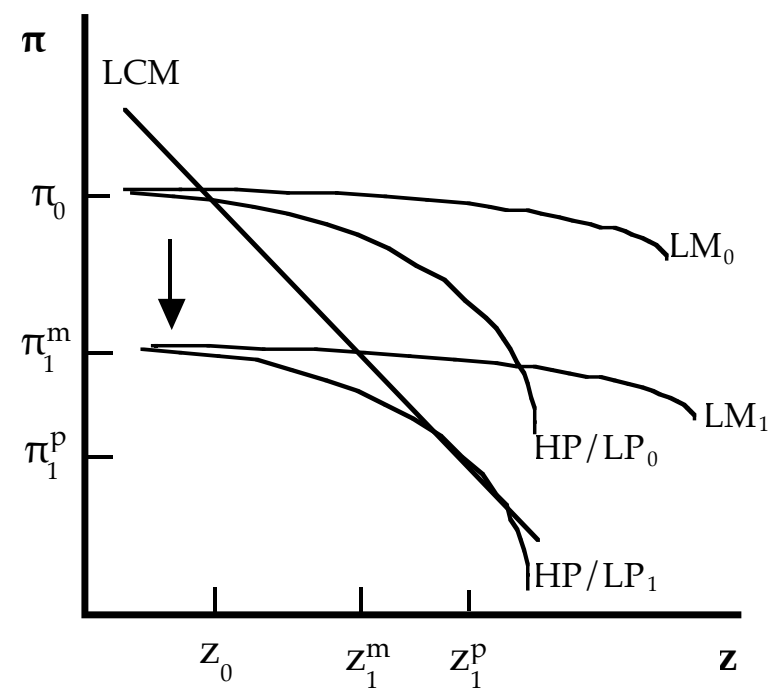

Figure 3a: Low capital mobility and an increase in women's wages

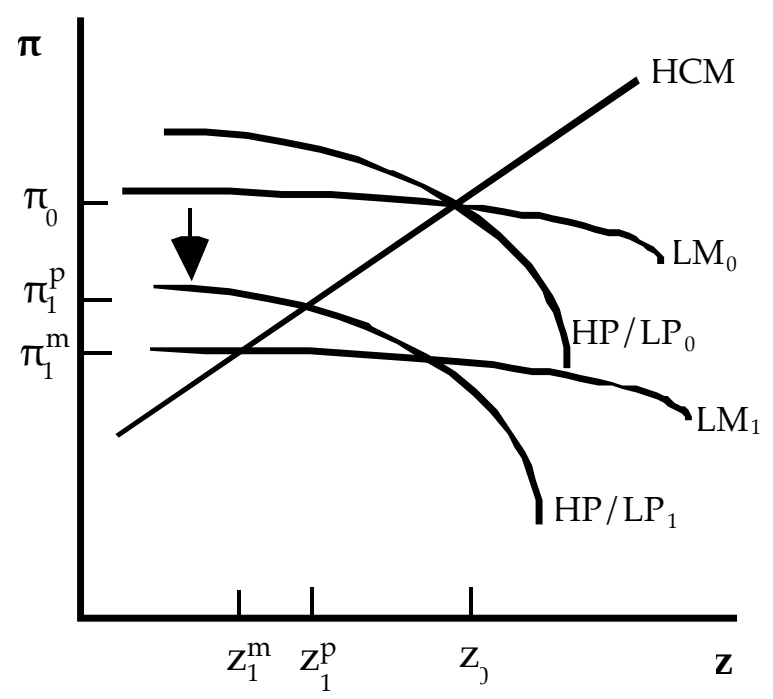

Figure 3b: High capital mobility and an increase in women's wages 


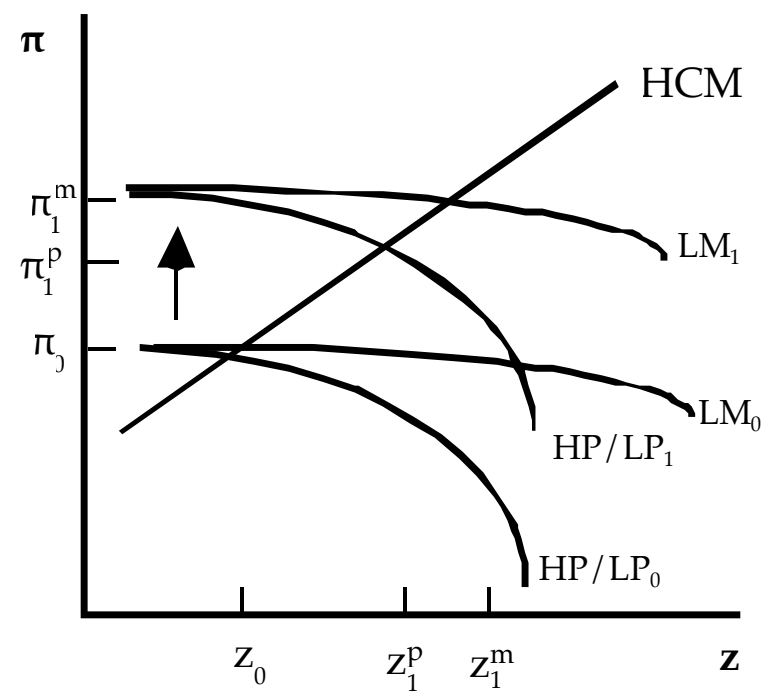

Figure 4: Improvements in labor productivity with high capital mobility 


\section{Appendix: Comparative Statics for Section IV}

\section{A1. Assigning a Functional Form}

In order to make the comparative statics more tractable, I have assigned simple linear functional forms for both the PE and IS schedules that correspond to their specifications in table one (variable explanations are recorded in table one as well).

Producer's Equilibrium (PE)

$$
\begin{array}{ll}
P E(\pi, z)=\pi=1-\frac{w_{0}+w(z)}{p q} \quad \text { where } \quad & w_{f}=w_{0}+w(z) \\
& w^{\prime}(z)=w_{z}>0 \\
& p=p_{x} \\
& q=q_{f}
\end{array}
$$

Investment-Savings (IS)

$$
\begin{aligned}
& I S(\pi, z)=i_{0}+b \pi+c z=s \pi z a-\left(n x_{0}+f \pi+g z\right) \\
& \text { where } \quad b, c, f>0 \\
& g<0
\end{aligned}
$$

\section{A2. Equilibrium}

$$
\begin{aligned}
& I S(\pi, z)=i_{0}+b \pi+c z-s \pi z a+n x_{0}+f \pi+g z=0 \\
& P E(\pi, z)=\pi+\frac{w_{0}+w(z)}{p q}-1=0
\end{aligned}
$$

\section{A3. Solving for changes in $\pi^{*}, z^{*}$ via Cramer's Rule}

Since getting the solution $\pi *, z *$ involves a quadratic, and the stability conditions ensure that the implicit function theorem holds, ${ }^{1}$ it is convenient to use Cramer's rule to solve for the comparative statics.

$$
\left[\begin{array}{ll}
I S_{\pi} & I S_{z} \\
P E_{\pi} & P E_{z}
\end{array}\right]\left[\begin{array}{l}
d \pi \\
d z
\end{array}\right]=\left[\begin{array}{c}
-I S_{x} d x \\
-P E_{x} d x
\end{array}\right]
$$

\footnotetext{
1 The conditions for stability of the IS-PE system ensure that the Jacobian matrix of that system does not equal zero.
} 
The preceding is a sort of short-hand for the problem. The first matrix on the left hand side of this equation is the Jacobian matrix of the system when it is in equilibrium; its determinant shall be written as $|J|$, and the superscript " $\mathrm{H}$ " refers to the high capital mobility case while "L" refers to the low capital mobility case. On the right hand side, $x$ refers to any of the exogenous variables. Subscripts indicate partial derivatives.

Some points about how the signs of this system vary with capital mobility are in order. For both regimes, $|J|>0 .^{2}$ The following details signs for the Jacobian's elements in each case.

\section{high capital mobility}

$$
\begin{aligned}
& I S_{\pi}=(b-s z a+f)>0 \\
& I S_{z}=(c-s \pi a+g)<0 \\
& P E_{\pi}=1>0 \\
& P E_{z}=w_{z} / p q>0 \\
& \left|J^{H}\right|=I S_{\pi} P E_{z}-I S_{z} P E_{\pi}>0
\end{aligned}
$$

\section{low capital mobility}

$$
\begin{aligned}
& I S_{\pi}=(b-s z a+f)<0 \\
& I S_{z}=(c-s \pi a+g)<0 \\
& P E_{\pi}=1>0 \\
& P E_{z}=w_{z} / p q>0 \\
& \left|J^{L}\right|=I S_{\pi} P E_{z}-I S_{z} P E_{\pi}>0
\end{aligned}
$$

\section{A4. An increase in aggregate demand}

\section{high capital mobility}

$\frac{d \pi^{*}}{d i_{0}}=\frac{-P E_{z}}{\left|J^{H}\right|}<0$

$\frac{d z^{*}}{d i_{0}}=\frac{-P E_{\pi}}{\left|J^{H}\right|}>0$

$\frac{\partial\left(d \pi * d i_{0}\right)}{\partial w_{z}}=\frac{p q(c-s \pi a+g)}{D^{2}}<0$

$\frac{\partial\left(d z * d i_{0}\right)}{\partial w_{z}}=-\frac{(b-s z a+f)}{p q\left|J^{H}\right|^{2}}<0$

\section{low capital mobility}

$$
\begin{aligned}
& \frac{d \pi^{*}}{d i_{0}}=\frac{-P E_{z}}{\left|J^{L}\right|}<0 \\
& \frac{d z^{*}}{d i_{0}}=\frac{-P E_{\pi}}{\left|J^{L}\right|}>0
\end{aligned}
$$

$\frac{\partial\left(d \pi * / d i_{0}\right)}{\partial w_{z}}=\frac{p q(c-s \pi a+g)}{D^{2}}<0$

$\frac{\partial\left(d z * d i_{0}\right)}{\partial w_{z}}=-\frac{(b-s z a+f)}{p q\left|J^{L}\right|^{2}}>0$

where $D=w_{z}(b-s z a+f)-p q(c-s \pi a+g)$

and $w_{z}=$ slope of the PE curve

\footnotetext{
${ }^{2}$ In the HCM case, this follows directly from the conditions for the positive slope. In the LCM regime, this follows from the conditions for stability.
} 
An exogenous change in investment has the same effect on equilibrium output and profit share in both regimes: profit share declines and output increases, but the size of the effect is greater in the LCM regime since its Jacobian is a smaller, positive number. An exogenous change in net exports works the same way as investment.

The difference between the cases of HP/LP and LM is represented via a steepening of the slope of the PE curve - an increase in the value of $w_{z}$, which actually makes the PE slope more negative. In both the cases of high and low capital mobility, a movement towards patriarchal dominance (an increase in $w_{z}$ ) increases the negative effect of an increase in investment on profit share. In terms of the effects on output, the two cases differ. In the low capital mobility case, a steepening of the PE slope increases the positive impact of an increase in investment on output. In the high capital mobility case, this steepening lessens the positive impact.

\section{A5. A decline in wage discrimination}

\section{high capital mobility}

$$
\begin{aligned}
& \frac{d \pi^{*}}{d w_{0}}=\frac{I S_{z}}{p q\left|J^{H}\right|}<0 \\
& \frac{d z^{*}}{d w_{0}}=\frac{-I S_{\pi}}{p q\left|J^{H}\right|}<0
\end{aligned}
$$$$
\frac{\partial\left(d \pi * / d w_{0}\right)}{\partial w_{z}}=-\frac{(c-s \pi a+g)(b-s z a+f)}{D^{2}}>0
$$$$
\frac{\partial\left(d z * / d w_{0}\right)}{\partial w_{z}}=\frac{(b-s z a+f)^{2}}{D^{2}}>0
$$

\section{low capital mobility}

$$
\begin{aligned}
& \frac{d \pi^{*}}{d w_{0}}=\frac{I S_{z}}{p q\left|J^{L}\right|}<0 \\
& \frac{d z^{*}}{d w_{0}}=\frac{-I S_{\pi}}{p q\left|J^{L}\right|}>0
\end{aligned}
$$

$\frac{\partial\left(d \pi * / d w_{0}\right)}{\partial w_{z}}=-\frac{(c-s \pi a+g)(b-s z a+f)}{D^{2}}<0$

$\frac{\partial\left(d z * / d w_{0}\right)}{\partial w_{z}}=\frac{(b-s z a+f)^{2}}{D^{2}}>0$

A decline in the gender wage gap is represented as an exogenous increase in women's wages, and there are differences by regime. In the high capital mobility case, profit share and output fall. Conversely, in the low capital mobility case, profit share falls but output increases.

There are differences in these impacts as the gender regime changes as well. In the high capital mobility case, a steepening of the PE slope decreases the negative effect of an increase in women's wages on profit share and lowers the negative impact on output. In the low capital mobility case, this move towards patriarchal dominance increases the negative effect of a wage increase on profit share, while increasing the positive impact on output. 


\section{A6. An increase in women's productivity}

\section{high capital mobility}

$\frac{d \pi^{*}}{d q}=\frac{-I S_{z}}{p q^{2}\left|J^{H}\right|}>0$

$\frac{d z^{*}}{d q}=\frac{I S_{\pi}}{p q^{2}\left|J^{H}\right|}>0$

$\frac{\partial(d \pi * / d q)}{\partial w_{z}}=\frac{q(c-s \pi a+g)(b-s z a+f)}{\left(p q^{2}\left|J^{H}\right|\right)^{2}}<0$

$\frac{\partial\left(d z^{*} / d q\right)}{\partial w_{z}}=-\frac{q(b-s z a+f)^{2}}{\left(p q^{2} \mid J^{H}\right)^{2}}<0$

\section{low capital mobility}

$$
\begin{aligned}
& \frac{d \pi^{*}}{d q}=\frac{-I S_{z}}{p q^{2}\left|J^{L}\right|}>0 \\
& \frac{d z^{*}}{d q}=\frac{I S_{\pi}}{p q^{2}\left|J^{L}\right|}<0
\end{aligned}
$$

$\frac{\partial(d \pi * / d q)}{\partial w_{z}}=\frac{q(c-s \pi a+g)(b-s z a+f)}{\left(p q^{2}\left|J^{L}\right|\right)^{2}}>0$

$\frac{\partial(d z * / d q)}{\partial w_{z}}=-\frac{q(b-s z a+f)^{2}}{\left(p q^{2}\left|J^{L}\right|\right)^{2}}<0$

An increase in women's productivity increases both profit share and output in the high capital mobility case, but that same increase in profit share brings about a decline in output in the low capital mobility case because of the transfer from wages to profits.

In the high capital mobility case, an increase in $w_{z}$ lowers the positive impact of an increase in women's labor productivity on the profit share and output. In the low capital mobility case, this steepening of the PE slope increases the positive effect on profit share and increases the negative effect on output. 